\title{
Evaluation of Livestock Waste Management to Energy Biogas (Case Study: Jetak Village, Getasan Sub District)
}

\author{
Andhina putri1 ${ }^{1,3 *}$, and P.Purwanto ${ }^{1,2}$ \\ ${ }^{1}$ Doctoral Program of Environmental Science, School of Postgraduate Studies, Diponegoro University, Semarang, Indonesia \\ ${ }^{2}$ Faculty of Chemical Engineering, Diponegoro University, Semarang, Indonesia \\ ${ }^{3}$ Teacher Training Institute and Educational Science Veteran, Semarang, Indonesia
}

\begin{abstract}
The purpose of this research is to know how to manage livestock waste into biogas energy in Jetak Village, Semarang Regency. The method used qualitative descriptive with qualitative descriptive approach. The technique of determining key informants was done by purposive sampling. Data were obtained from cattle ranchers who lived in the study sites through interviews, observation and documentation. The result of this research is the community biogas users in Jetak Village who get assistance from DAK (Special Budget Fund) in 2008 not yet fully utilize this technology optimally. This can be seen from some of the user community that experienced obstacles such as cracking of main digester, utilization of less than maximum energy,etc. The community of users who get this assistance is a community that has a large number of farms about 15-20 head of cattle, so it is expected that the potential of gas produced greater and can help the surrounding community to meet the needs of energy. Each user community distributes the gas to five local people. At this time some of the installation has been damaged so that people again use LPG gas for energy fulfillment, especially cooking activity.
\end{abstract}

Keywords: biogas ;energy; cattle; dung; participation

\section{Introduction}

Energy is a resource that has an important role in human life. Currently almost all human activities require energy. This is because most human activities no longer use human power as its driving components but machines. Currently the use of energy increases in number as the population increases. The energy source used so far is mostly derived from fossil fuels such as petroleum, gas, coal and others. This energy source of the formation process takes a long time to millions of years so it can be said as non renewable energy. In addition, the environmental impact of fossil energy use is the increase in greenhouse gases in the air which is believed to be one of the causes of global warming. Thus, it takes an alternative source of alternative energy to reduce the rate of unpredictable energy use [1].

State of Indonesia is one of the countries that have the potential to develop alternative renewable energy sources. Livestock sector is one sector that produces waste abundantly in the form of solid or liquid and has not been done intensive management that can cause environmental pollution. Livestock waste is the result of discharges from livestock business which has been a problem in life. One cow weighing about $450-500 \mathrm{~kg}$ can produce about 25-30 $\mathrm{kg}$ of feces and urine every day. If one farmer has about 4-5 head of cattle, then the amount of feces produced about $150 \mathrm{~kg} /$ day. With the amount of feces produced so large every day and not done processing then it will disrupt the surrounding environment [2].

One of the right solutions to reduce the negative impact of livestock waste is intensive management. Waste farming can be one source of alternative energy that is biogas energy. Biogas is a technology for energy generation by utilizing waste such as agricultural waste, livestock waste and human waste. In addition to be used as an alternative energy biogas is one alternative in reducing environmental problems such as air pollution, soil pollution and global warming. Results from making biogas other than as a source of energy but also can be used as byproducts such as fertilizer produced from sludge so as to increase income for the farmers community itself [3]. The use of biogas energy can be one of the actions that are in accordance with the principles of sustainable development, namely the energy needs in the development of all community groups can be fulfilled properly. In addition, the use of biogas energy is one of the sources of low-carbon energy so that it will indirectly

*Corresponding author:andhinaputri86@yahoo.co.id 
form low-carbon community groups to achieve the goals in climate-friendly development.

Jetak village is one of the villages that most of the people as farmers as well as breeders. Dairy cows in the village of Jetak on average amounted to 3-5 tail / kk. This is what prompted the Government to declare Jetak Village as Energy Independent Village. It is based on the abundance of raw materials to make alternative energy such as biogas energy. In 2008 Jetak Village received assistance to build biogas installation with Special Budget Fund (DAK). This assistance is aimed at community farmers who own livestock with large capacity. Based on that, the researcher is interested to know the condition of waste management of dairy cattle into biogas that has been implemented in Jetak Village, Semarang Regency.

\section{Method}

The research was conducted in Aptil-June 2017 in Jetak Village, Getasan Sub-district Central Java. The method used in this research is qualitative descriptive with qualitative descriptive approach. This research uses purposive sampling in determining key informant that is election done with certain purpose and consideration [4]. Community of biogas energy users as much as 18 respondents and community leaders in Jetak Villag as many as 3 respondents is a key informant in this research.

To complement the main data needed from the community of biogas energy users in the study sites are in-depth interviews, observation and documentation. The process of data analysis is done with three stages of data collection phase, data reduction and data presentation. Data analysis techniques use horizonalitation which the development of meaning groups into various themes of textural and structural descriptions and the essential invariant structure stage, write a composite description that presents the "essence" of phenomena that focus on the shared experience of participants [5].

\section{Result and Disscussion}

Jetak village is one of the villages in Semarang Regency which has dairy farm. The area of land in Jetak village is used by the community for dry farming, community forest and moor. Jetak village is a mountainous area that has the carrying capacity of fertile soils, suitable climatic conditions and the existence of plantation and agricultural land used by the community to support the availability of their dairy cattle feed.

Jetak village has terrain topography with latitude coordinates of 7.3915 and longitude of 110.4814. The total area of Jetak Village is $2.94 \mathrm{~km}^{2}$ with the percentage of the area of $4.47 \%$. Jetak Village has 12 hamlets, $12 \mathrm{RW}$ and $33 \mathrm{RT}$. Geographically $\pm 35 \mathrm{~km}$ distance from the Capital District, located above sea level $\pm 850 \mathrm{~m}$ with the air scale between $18-26{ }^{\circ} \mathrm{C}$.
Jetak Village is one of the villages that have the potential of dairy cattle to be utilized as a source of biogas energy that becomes a source of alternative energy in fulfilling the energy needs of the community independently. In 2008 Jetak Village received assistance from the government

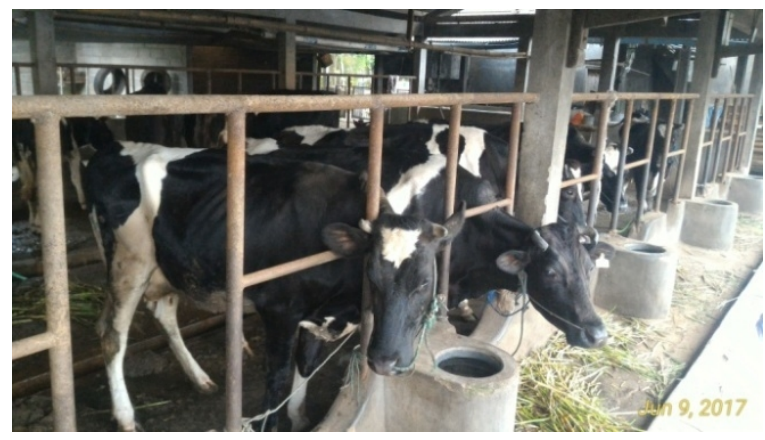

Fig.1. Dairy Cattle

with the Special Budget Fund (DAK) for people with large-scale farms. This assistance is given to three heads of households with the number of cows as much as 15-20 cows / head of family. The digester capacity is built $30 \mathrm{~m}^{3}$ with gas produced at $18 \mathrm{~m}^{3} /$ day. Determination of digester size is determined based on available raw materials and the amount of gas needed each day. If the built digester has too small size, the digester can't accommodate all the dirt produced every day. Conversely, if the digester size is too large, the produced gas is not optimal [6]. The capacity of the digester that was built in the village of Jetak was in accordance with the availability of raw materials available, but the use of gas produced was not maximal. Most users use biogas energy only for cooking needs. For lighting they still use electricity from PLN. This is because the lights used need special handling in their application. If there is damage to the community the user feels difficulties in repairing it. In addition, the components needed are often not easy to find. The gas produced by biogas users is not only used individually but communally which is distributed to five families head around.

In general, the pattern of raising livestock in the village of Jetak is carried out with an intensive caged system. This makes it easier for farmers to collect solid waste produced in one place. Most of the conditions of the breeder's cage building are simple, but the cage floor is cemented or plastered. The condition of the breeder's enclosure has been equipped with a sewer in the form of a small ditch with an elongated shape that is behind the cow, making it easier for the cage cleaning process. 


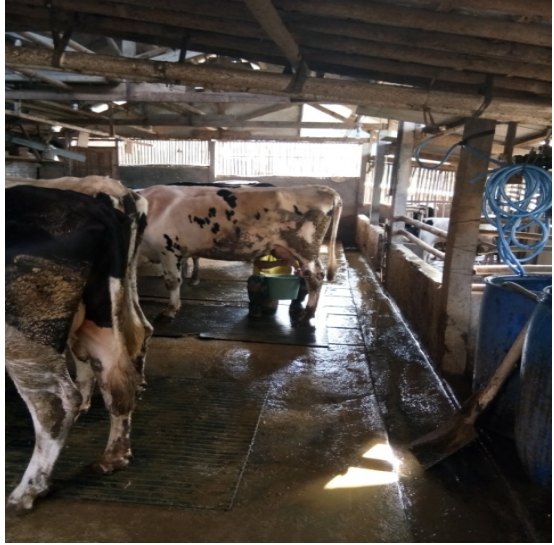

Fig.2. Condition of Livestock

At the front position there is a place for animal feed that is made specifically to facilitate farmers in feeding. This is an advantage in the use of biogas which minimizes the mixing of residual feed with dirt that can inhibit gas formation in the production process. By looking at the existing maintenance system in Jetak Village and the conditions of the cages there, indirectly the biogas users have prepared carefully to accept biogas technology as a new technology that can help them reduce fossil energy use. In addition, another positive side is the use of energy biogas that can change the pattern of maintenance of farmers, especially the biogas users. The implementation of the biogas program in the community can change the maintenance system that was formerly done with grazing to become intensively grounded [7].

The community of biogas users and beneficiaries finds it very helpful with the biogas energy. People feel that biogas technology is easy to apply. The resulting gas is used to meet daily energy needs such as cooking and lighting. Facilities and infrastructure associated with biogas energy operations are adequate where every major component required in the biogas manufacturing process is available. In the use of energy biogas, the user does not experience difficulties both in the process of making and operating the digester. Over time, there are several user communities that currently do not use energy biogas. There are several factors that become the basis of the nonuse of biogas energy, among others, the damage in some installation points that cause can't be used for biogas energy production process.

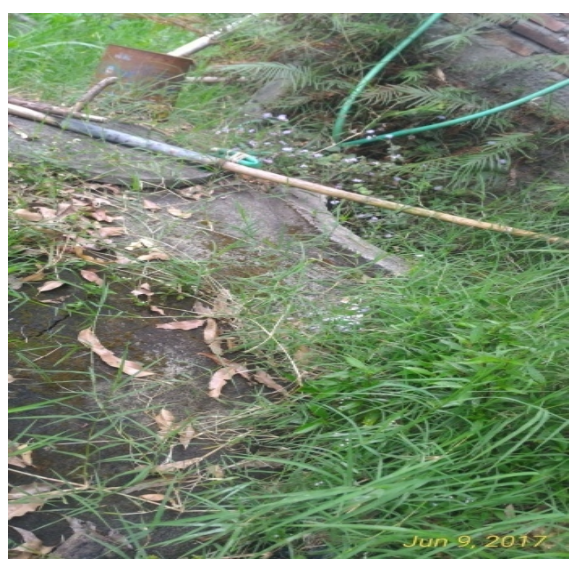

Fig.3. Cracked Digester

The crack in the digester is one example of the use of biogas energy to stop. Improvements made by the user community are constrained due to the digester used by the fixed dome model. The selection of the right digester is one of the requirements for the construction of a biogas installation that is adjusted to the characteristics of the community and the location of the digester. In general, fixed dome models are built in the ground with raw materials for cement, sand, stone and brick. The design of the digester is made airtight and the structure must be strong to withstand gas leakage. This is what makes if there is damage to the digester, especially cracks in the dome will be difficult to repair. The advantages of fixed dome digester are easier maintenance and lower costs. While the weakness is that in the manufacturing process takes a long time, is susceptible to cracking, its position cannot be moved and its construction requires quite expensive costs. The pores in the digester that are large enough cause the gas produced to leak easily, making it difficult to make early detection and repair [9].

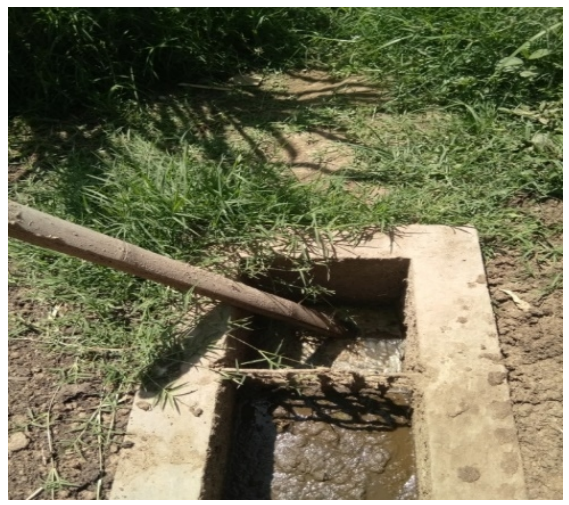

Fig.4. Inlet on Installation 
Factors that cause installation damage are the process of making biogas is not done correctly, lack of concern of the user community in maintaining available installations as well as lack of community interest in maximizing the use of biogas energy. Damage to the installation is generally caused by a blockage in the digester tube because of the low motivation of the community to carry out regular maintenance. When there is damage to the digester, the type of dome still requires special handling, so it requires human resources who have high skills and expertise. For damage to the main tube such as cracking requires special handling and expensive costs. The user community should be able to anticipate this by performing regular maintenance according to the operational standard of energy biogas. The user community should provide filters inside the inlet. This is one way to anticipate that foreign objects do not enter into the main installation and interfere with the gas formation process. Research conducted by Cvetkovic et al (2014)[8] of various designs and standards in equipment design creates problems with equipment maintenance. For minor damage the user community can improve individually, but for the large damage the user community needs assistance from stakeholders both technically and materially.

In addition, the availability of other energy is an important factor that influences the use of energy biogas by the community. This is based on the existence of other energy choices in meeting the energy needs of the community. The use of biogas energy has not been done optimally where people prefer to use other energy such as $3 \mathrm{~kg}$ LPG for cooking needs. People assume that using LPG is easier than using energy biogas where they can save time and energy to do other work. One of the factors can accelerate the development of biogas if it is difficult to obtain other energy in transmigration settlements. If there are other energies that have been utilized such as firewood, kerosene and electricity that are easily available, low prices, and there are locations, then the use of biogas energy is no longer attractive [10]. For this reason, energy biogas must have higher competitiveness than other energy. In the utilization of energy biogas, the optimal target of the community using biogas must be appropriate so that the appreciation of the added value from the reduction of fuel purchases is truly felt. Statistically the choice of households for energy biogas is positively correlated with the use of firewood and charcoal, although in some households it still depends on traditional energy. With the availability of biogas digester household energy consumption is increasing. In addition, factors that influence household energy choices include livestock size, working age, gender, access, credit services and livestock mobility [11].

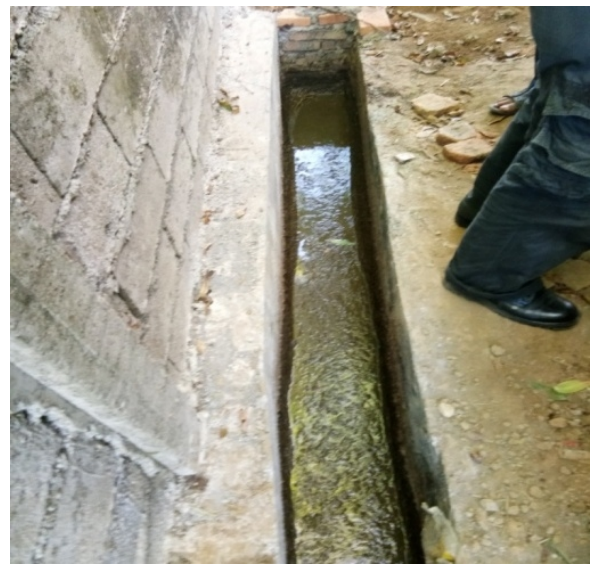

Fig.5. Outlet on Installation

In the utilization of the biogas energy side, the user community has not utilized it maximally. Community users assume that processing side results requires extra time and energy. They must really take the time and energy for the process of making liquid and solid fertilizers that are ready to be sold to the market. At present, the user community utilizes biogas energy in the form of sludge / slurry for privately owned plantation land by flowing it from the outlet directly using the pipe. Rural in China biogas residues in the form of slurry are used directly as fertilizer without processing. Most of the biogas residues in the form of slurry are disposed of directly to the nearest water body which results in serious threats to the environment, drinking water sources and agricultural ecology. Biogas fertilizer in the form of anaerobic fermented residues not only contains nutrients, but heavy metals, pathogenic pesticide residues and bacteria [12]. Plantation products in the form of green grass are used to feed their own livestock, so the user community has indirectly applied the concept of "zero waste".

Zero Waste is an activity that eliminates waste in the production process by managing an integrated process by minimizing the waste formed. Indirectly energy provides additional benefits in terms of the environment where no waste is wasted if properly utilized and increases the income of the user community if the byproducts/ slurry can be processed into other products [13].

\section{Conclusion}

Overall the implementation of energy biogas has not gone well. This can be seen from some users who still have difficulties in repairing installation damage. In addition, the motivation of the user community to conduct regular maintenance is still low. This has caused several installations to be damaged both on a large and small scale. The availability of other energy is one of the 
obstacles to the use of biogas energy has not been maximized. The biogas user community has not carried out the processing of by-products of biogas energy in the form of intensive slurry. Slurry / sludge that came out of the outlet only flowed into the garden near the cage. However, the community using biogas in the village of Jetak as a whole has realized the importance of environmental cleanliness. This can be seen from the condition of the cattle shed and the maintenance patterns applied by the current biogas users. Unwittingly, the community using biogas in the village of Jetak has implemented the Zero Waste system where they utilize plantation products for animal feed and fertilizers used for plantations, namely by-products of energy biogas production.

\section{Reference}

1. Wahyuni, Sri ; Suryahadi ; Amirullah, Saleh. 2009. Analisis Kelayakan Pengembangan Biogas Sebagai Energi Alternatif Berbasis Individu Dan Kelompok Peternak. Bogor : PT. Media Inovasi Transfer. Manajemen IKM, September 2009 (217-224) ISSN 2085-3418

2. Fathurrohman, Amang; Muh.Aniar Hari; S.Aminatuz Zukhriyah; Moh. Awaludin Adam. 2016. Persepsi peternak sapi dalam pemanfaatan kotoran sapi menjadi biogas di Desa Sekarmojo Purwosari Pasuruan. Universitas Yudharta Pasuruang : Jurnal Ilmu-Ilmu Peternakan 25 (2):3642 ISSN : 08523581 E-ISSN : 9772443D76DD3

3. Wahyuni, Sri. 2011. Menghasilkan Biogas dari Aneka Limbah. Jakarta : Agro Media Pustaka

4. Sugiyono. 2010. Memahami Penelitian Kualitatif. Bandung : Penerbit CV. Alfabeta

5. Cresswell, J. W. 2014. Penelitian kualitatif dan design riset: memilih di antara lima. Edisi ketiga. Pustaka Pelajar. Yogyakarta
6. Wahyuni, Sri. 2017. Menghasilkan Biogas dari Aneka Limbah. Jakarta : Agro Media P

7. Syamsuddin, A.Rahman Mappangaja ; Asmuddin. 2011. Analisis Manfaat Program Biogas Asal Ternak Bersama Masyarakat (BATAMAS) Kota Palopo (Studi kasus Kelompok Tani Kampulang Kecamatan Wara Selatan Kota Palopo). (www.118.97.33.150/jurnal/../0c04ca421fe598794 5c80a6200487781.pdf)

8. Cvetkovic, Slobodan ; Tatjana KR ; Bojana V; Mirjana K. 2014. Potentials and Status of Biogas as Energy Source in the Republic of Serbia. Serbia : ScienceDirect (Renewable and Sustainable Energy Reviewes 31 407-416)

9. Wahyuni, Sri. 2008. Biogas. Depok : Penebar Swadaya

10. Ariani, Enny. 2011. Faktor Keberhasilan Pengembangan Biogas di Permukiman Transmigrasi Sungai Rambutan. Jakarta : Pusat Penelitian dan PengembanganKetransmigrasian. (www.pustlitbangtrans.depnakertrans.go.id/..)

11. Berhe, Melaku ; Dana Hoag ; Girmay Tesfay ; Catherine Keske. 2017. Factors Influencing the Adoption of Biogas Digesters in Rural Ethiopia. Ethiopia ; Springers. (Energy, Sustainability and Society $7: 10$ )

12. Chen, Yu; Wei Hu; Yongzhong Feng; Sandra Sweeney. 2014. Status and Prospect of Rural Biogas Development in China. China : ScienceDirect. (Renewable and Sustainable Energy Reviews 39 679-685)

13. Sulaeman, Deden. 2008. Zero Waste (Prinsip Menciptakan Agro-industri Ramah Lingkungan). Jakarta Selatan : Departemen Pertanian 